\title{
Ambient Particulate Matter Air Pollution in Mpererwe District, Kampala, Uganda: A Pilot Study
}

\author{
Stephan Schwander, ${ }^{1}$ Clement D. Okello, ${ }^{2}$ Juergen Freers, ${ }^{2}$ Judith C. Chow, ${ }^{3}$ \\ John G. Watson, ${ }^{3}$ Melody Corry, ${ }^{4}$ and Qingyu Meng ${ }^{1}$ \\ ${ }^{1}$ Department of Environmental and Occupational Health and Center for Global Public Health, Rutgers School of Public Health, \\ Piscataway, NJ, 08854, USA \\ ${ }^{2}$ Department of Medicine, Makerere University College of Health Sciences, Makerere University School, Kampala, Uganda \\ ${ }^{3}$ Division of Atmospheric Sciences, Desert Research Institute, Reno, NV 89512, USA \\ ${ }^{4}$ Division of Global Affairs, Rutgers the State University of New Jersey, Newark, NJ 07102, USA
}

Correspondence should be addressed to Stephan Schwander; schwansk@sph.rutgers.edu and

Qingyu Meng; mengqi@sph.rutgers.edu

Received 18 August 2013; Accepted 22 October 2013; Published 17 February 2014

Academic Editor: Pam R. Factor-Litvak

Copyright (C) 2014 Stephan Schwander et al. This is an open access article distributed under the Creative Commons Attribution License, which permits unrestricted use, distribution, and reproduction in any medium, provided the original work is properly cited.

Air quality in Kampala, the capital of Uganda, has deteriorated significantly in the past two decades. We made spot measurements in Mpererwe district for airborne particulate matter $\mathrm{PM}_{2.5}$ (fine particles) and coarse particles. PM was collected on Teflon-membrane filters and analyzed for mass, 51 elements, 3 anions, and 5 cations. Both fine and coarse particle concentrations were above $100 \mu \mathrm{g} / \mathrm{m}^{3}$ in all the samples collected. Markers for crustal/soil (e.g., Si and $\mathrm{Al}$ ) were the most abundant in the $\mathrm{PM}_{2.5}$ fraction, followed by primary combustion products from biomass burning and incinerator emissions (e.g., $\mathrm{K}$ and $\mathrm{Cl}$ ). Over $90 \%$ of the measured $\mathrm{PM}_{2.5}$ mass can be explained by crustal species (41\% and 59\%) and carbonaceous aerosol (33\%-55\%). Crustal elements dominated the coarse particles collected from Kampala. The results of this pilot study are indicative of unhealthy air and suggest that exposure to ambient air in Kampala may increase the burden of environmentally induced cardiovascular, metabolic, and respiratory diseases including infections. Greater awareness and more extensive research are required to confirm our findings, to identify personal exposure and pollution sources, and to develop air quality management plans and policies to protect public health.

\section{Introduction}

Air pollution is an increasing problem in urban dwellings worldwide. The World Health Organization (WHO) ranks indoor air pollution (from biomass fuel combustion) and urban outdoor air pollution 10th and 14th, respectively, among 19 leading risk factors for global mortality [1]. There is indisputable epidemiologic evidence that air pollution exposure in humans increases not only the risk of respiratory conditions such as asthma and respiratory tract infections but also cardiovascular disease and metabolic diseases such as diabetes mellitus $[2,3]$. In the developing world, air pollution presents a particular threat to the health of populations in cities that are growing in a fast, poorly planned, and unregulated manner $[4,5]$.
This is the case in Kampala, Uganda, where air quality has deteriorated significantly during the past two decades in parallel with the fast-paced economic development. Kampala is the capital of Uganda in East Africa, a country with a rapidly increasing population and expanding economic growth. With a growing middle class, Uganda, and specifically Kampala, has seen fast expanding vehicular traffic comprised of imported second hand and reconditioned cars, aging, exhaust-unregulated cars, trucks, buses, and motorcycles. Furthermore, the national economic strategy gives priority to the industrial and manufacturing sectors and has promoted and realized a rise in cottage and other larger industries within the city. In addition to the ever growing road traffic and unregulated industrial emissions, waste burning by 


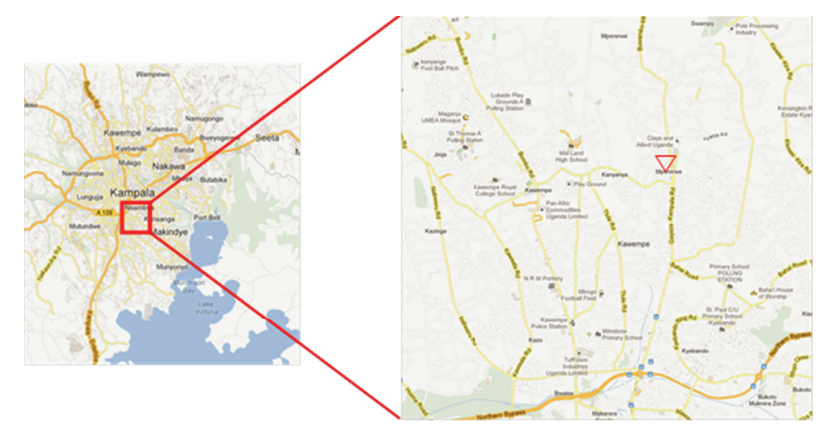

FIGURE 1: Map showing Kampala with detail of the sampling area. Sampling location indicated with red triangle. Source: Google maps (https://maps.google.com/maps?hl=en\&tab=wl).

individuals to manage uncollected waste, also contributes to the deterioration of air quality in Kampala.

However, reports on air pollution in Kampala are primarily anecdotal [6-8]. An ongoing study shows an increase of ischemic heart disease from virtually absent up to the end of the 1990s to more than $10 \%$ of all admissions on the Mulago University Hospital cardiology ward in 2011. As part of an effort to preliminarily characterize airborne particulate matter (PM) within Kampala, we made spot measurements of ambient PM in a typical bustling, low-income, mixed commercial, and residential section of the city (Mpererwe District). This paper provides a summary of the findings.

\section{Methods}

To characterize the content of air pollution PM, we made spot measurements in Mpererwe District, Kawempe South Division, at Kalerwe Market, 80 meters east from Gayaza Kampala Road in Kampala City (Figure 1-Map). Employing a Sioutas Personal Cascade Sampler (SKC Inc., Eighty Four, PA, USA) with a flow rate of 9 liters per minute, we collected fine particles $\left(\mathrm{PM}_{2.5}\right.$, or particles with aerodynamic diameters less than $2.5 \mu \mathrm{m})$ and coarse particles $\left(\mathrm{PM}_{7-2.5}\right)$ (this fraction contains total suspended particles with aerodynamic diameters greater than $2.5 \mu \mathrm{m}$ ) during two 24-hour sampling periods (6:30 p.m. to 6:30 p.m., Local Standard Time [LST]) between December 31st, 2012, and January 1st, 2013, and between January 2nd, 2013, and January 3rd, 2013. PM were collected on Teflon-membrane filters $(37 \mathrm{~mm}, 2 \mathrm{~mm}$ pore, Pallflex Gelman Scientific, Ann Arbor, MI, USA). The personal PM monitor as well as a Leland Legacy Pump (SKC Inc., Eighty Four, PA, USA) were installed 3 meters above ground level, on the outside wall of a single story structure under a $50 \mathrm{~cm}$ protruding metal sheet roof.

$\mathrm{PM}_{2.5}$ and $\mathrm{PM}_{\text {coarse }}$ samples were removed from the monitors at the end of each sampling period, stored in plastic petri dishes, sealed and transferred to the USA for further analysis. Filters were equilibrated under a temperature $\left(21.5 \pm 1.5^{\circ} \mathrm{C}\right)$ and relative humidity $(35 \pm 5 \%)$ controlled environment before gravimetric analysis following the US Environmental Protection Agency (EPA) protocol at the Environmental and Occupational Health Sciences Institute (EOHSI) in New
Jersey. $\mathrm{PM}_{2.5}$ samples were submitted for elemental analysis by X-ray fluorescence (XRF) including 51 elements from $\mathrm{Na}$ to $\mathrm{U}$ (see Table 1 and [10]). Three anions $\left(\mathrm{Cl}^{-}, \mathrm{NO}_{3}{ }^{-}\right.$, and $\mathrm{SO}_{4}{ }^{2-}$ ) and five cations $\left(\mathrm{NH}^{+}, \mathrm{Na}^{+}, \mathrm{Mg}^{2+}, \mathrm{Ca}^{2+}\right.$, and $\mathrm{K}^{+}$) were measured for $\mathrm{PM}_{2.5}$ by ion chromatography (IC) [11]. Particle loadings from the personal PM monitor are centered on a slit, so only 18 elements were analyzed by inductively coupled plasma-mass spectrometry (ICP-MS).

\section{Results}

Based on the PM mass, fine and coarse particle concentrations were $104.9 \mu \mathrm{g} / \mathrm{m}^{3}$ and $132.7 \mu \mathrm{g} / \mathrm{m}^{3}$ for the sample from December 31, 2012 and $103.7 \mu \mathrm{g} / \mathrm{m}^{3}$ and $208.1 \mu \mathrm{g} / \mathrm{m}^{3}$ for the sample from January 2, 2013, respectively.

$\mathrm{PM}_{2.5}$ mass concentrations and chemical compositions are listed in Table 2, which includes typical marker species representing major $\mathrm{PM}_{2.5}$ sources, such as soil (Al, $\mathrm{Si}, \mathrm{Ca}$, $\mathrm{Fe}$, and $\mathrm{Ti}$ ), oil combustion ( $\mathrm{V}$ and $\mathrm{Ni}$ ), biomass combustion $\left(\mathrm{K}^{+}\right)$, traffic $(\mathrm{Pb}$ and $\mathrm{Zn})$, incinerator $(\mathrm{Cl})$, and secondary $\mathrm{PM}\left(\mathrm{SO}_{4}{ }^{2-}\right)$. A full list of all measured $\mathrm{PM}_{2.5}$ species is in Table 1. The relative abundance of major $\mathrm{PM}_{2.5}$ species is similar across the two sampling days. Markers for crustal/soil are the most abundant, followed by primary combustion sources, such as biomass burning and incinerator emissions. Elevated water-soluble to total potassium ratio $\left(\mathrm{K}^{+} / \mathrm{K}=0.91\right)$ for both $\mathrm{PM}_{2.5}$ samples confirms an abundance of biomass burning during the sampling period [12]. An exploratory $\mathrm{PM}_{2.5}$ mass reconstruction was conducted based on major species measured, that is, $\mathrm{SO}_{4}{ }^{2-}, \mathrm{NO}_{3}{ }^{-}, \mathrm{Al}, \mathrm{Si}, \mathrm{Ca}, \mathrm{Fe}$, and $\mathrm{Ti}$, and closing the mass balance by assuming the remaining mass was contributed by carbon species [13]. Figure 2 illustrates the percent contributions of $\mathrm{SO}_{4}{ }^{2-}, \mathrm{NO}_{3}{ }^{-}$, crustal sources, and carbon. Over $90 \%$ of measured $\mathrm{PM}_{2.5}$ mass can be explained by crustal species and carbonaceous aerosol. Table 3 shows the elemental concentrations measured for $\mathrm{PM}_{\text {coarse }}$ samples. Abundant ( $>200 \mathrm{ng} / \mathrm{m}^{3}$ ) crustal species (e.g., Al, Ca, and Fe) are found with large sample-to-sample variations.

The meteorological conditions during the sampling period are presented in Table 4. Mean temperatures across the four sampling dates ranged from $21.7^{\circ} \mathrm{C}$ to $24.4^{\circ} \mathrm{C}$, with dew point temperatures between 18.9 and $20.0^{\circ} \mathrm{C}$ and mean wind speeds between 6.4 and $8.1 \mathrm{Km} / \mathrm{hr}$.

\section{Discussion}

To the best of our knowledge, there is no known data/sample collection and public information available on type and concentrations of particulate matter in Kampala's air and studies of the associated human health impacts are extremely limited. There is clear evidence that air pollution in Kampala has increased in the last decade (Figure 3 ) and that awareness about this problem is mounting [6-8]. The limited findings of the current study clearly support these observations and indicate that exposure to ambient air in Kampala may raise public health concerns such as the burden of cardiovascular and respiratory diseases. $\mathrm{PM}_{2.5}$ mass concentrations observed 
TABLE 1: Concentrations of all measured $\mathrm{PM}_{2.5}$ species $\left(\mathrm{ng} / \mathrm{m}^{3}\right)$.

\begin{tabular}{|c|c|c|c|c|}
\hline $\mathrm{PM}_{2.5}$ species & Analytical method ${ }^{\mathrm{a}}$ & December 31, 2012-January 1, 2013 & January 2, 2013-January 3, 2013 & Limit of detection \\
\hline $\mathrm{Na}$ & $\mathrm{XRF}$ & 0 & 0.0 & 0.0 \\
\hline $\mathrm{Mg}$ & $\mathrm{XRF}$ & 0 & 0.0 & 23.7 \\
\hline $\mathrm{Al}$ & $\mathrm{XRF}$ & 5451 & 4097.6 & 17.6 \\
\hline $\mathrm{Si}$ & $\mathrm{XRF}$ & 9757 & 6739.5 & 0.9 \\
\hline $\mathrm{P}$ & $\mathrm{XRF}$ & 30 & 16.0 & 2.1 \\
\hline S & $\mathrm{XRF}$ & 1312 & 632.7 & 0.0 \\
\hline $\mathrm{Cl}$ & $\mathrm{XRF}$ & 1959 & 1047.5 & 0.1 \\
\hline $\mathrm{K}$ & $\mathrm{XRF}$ & 2969 & 1976.1 & 0.4 \\
\hline $\mathrm{Ca}$ & $\mathrm{XRF}$ & 3357 & 1628.8 & 7.2 \\
\hline Sc & $\mathrm{XRF}$ & 0 & 0.0 & 5.4 \\
\hline $\mathrm{Ti}$ & $\mathrm{XRF}$ & 779 & 491.7 & 0.4 \\
\hline $\mathrm{V}$ & $\mathrm{XRF}$ & 10 & 7.9 & 0.0 \\
\hline $\mathrm{Cr}$ & $\mathrm{XRF}$ & 16 & 8.9 & 0.2 \\
\hline $\mathrm{Mn}$ & $\mathrm{XRF}$ & 158 & 109.8 & 0.4 \\
\hline $\mathrm{Fe}$ & $\mathrm{XRF}$ & 7616 & 5400.2 & 4.5 \\
\hline Co & $\mathrm{XRF}$ & 0 & 0.0 & 0.7 \\
\hline $\mathrm{Ni}$ & $\mathrm{XRF}$ & 3 & 11.1 & 0.7 \\
\hline $\mathrm{Cu}$ & $\mathrm{XRF}$ & 16 & 10.3 & 0.4 \\
\hline $\mathrm{Zn}$ & $\mathrm{XRF}$ & 90 & 79.4 & 0.4 \\
\hline $\mathrm{Ga}$ & $\mathrm{XRF}$ & 0 & 0.0 & 0.0 \\
\hline As & $\mathrm{XRF}$ & 8 & 2.3 & 0.0 \\
\hline $\mathrm{Se}$ & $\mathrm{XRF}$ & 0 & 0.7 & 0.7 \\
\hline $\mathrm{Br}$ & $\mathrm{XRF}$ & 41 & 28.3 & 0.7 \\
\hline $\mathrm{Rb}$ & $\mathrm{XRF}$ & 15 & 7.3 & 0.2 \\
\hline $\mathrm{Sr}$ & XRF & 35 & 104.2 & 0.9 \\
\hline $\mathrm{Y}$ & $\mathrm{XRF}$ & 6 & 2.5 & 0.3 \\
\hline $\mathrm{Zr}$ & $\mathrm{XRF}$ & 56 & 29.9 & 1.9 \\
\hline $\mathrm{Nb}$ & $\mathrm{XRF}$ & 0 & 0.0 & 0.7 \\
\hline Mo & $\mathrm{XRF}$ & 0 & 0.0 & 0.7 \\
\hline $\mathrm{Pd}$ & XRF & 0 & 0.0 & 4.1 \\
\hline Ag & $\mathrm{XRF}$ & 0 & 0.0 & 0.7 \\
\hline $\mathrm{Cd}$ & $\mathrm{XRF}$ & 0 & 0.0 & 0.0 \\
\hline In & $\mathrm{XRF}$ & 0 & 2.2 & 2.6 \\
\hline $\mathrm{Sn}$ & $\mathrm{XRF}$ & 0 & 0.0 & 1.0 \\
\hline $\mathrm{Sb}$ & XRF & 0 & 0.0 & 8.3 \\
\hline Cs & $\mathrm{XRF}$ & 4 & 0.0 & 0.0 \\
\hline $\mathrm{Ba}$ & $\mathrm{XRF}$ & 0 & 0.0 & 12.3 \\
\hline $\mathrm{La}$ & $\mathrm{XRF}$ & 2 & 0.0 & 17.3 \\
\hline $\mathrm{Ce}$ & $\mathrm{XRF}$ & 0 & 0.0 & 34.4 \\
\hline $\mathrm{Sm}$ & XRF & 37 & 1.9 & 65.4 \\
\hline $\mathrm{Eu}$ & $\mathrm{XRF}$ & 0 & 0.0 & 30.9 \\
\hline $\mathrm{Tb}$ & $\mathrm{XRF}$ & 35 & 17.1 & 68.3 \\
\hline $\mathrm{Hf}$ & $\mathrm{XRF}$ & 0 & 0.0 & 0.0 \\
\hline $\mathrm{Ta}$ & $\mathrm{XRF}$ & 0 & 0.0 & 0.0 \\
\hline W & $\mathrm{XRF}$ & 0 & 0.0 & 1.7 \\
\hline Ir & $\mathrm{XRF}$ & 0 & 0.0 & 0.0 \\
\hline $\mathrm{Au}$ & $\mathrm{XRF}$ & 0 & 0.0 & 1.7 \\
\hline $\mathrm{Hg}$ & $\mathrm{XRF}$ & 0 & 0.0 & 0.0 \\
\hline $\mathrm{Tl}$ & XRF & 0 & 0.0 & 0.4 \\
\hline
\end{tabular}


TABle 1: Continued.

\begin{tabular}{lcccc}
\hline $\mathrm{PM}_{2.5}$ species & Analytical method $^{\mathrm{a}}$ & December 31, 2012-January 1, 2013 & January 2, 2013-January 3, 2013 & Limit of detection \\
\hline $\mathrm{Pb}$ & XRF & 23 & 18.6 & 1.2 \\
$\mathrm{U}$ & XRF & 0 & 0.0 & 0.0 \\
$\mathrm{Cl}^{-}$ & $\mathrm{IC}$ & 1984 & 1160.5 & 0.0 \\
$\mathrm{NO}_{3}{ }^{-}$ & $\mathrm{IC}$ & 2547 & 1502.4 & 72.6 \\
$\mathrm{SO}_{4}{ }^{2-}$ & IC & 3542 & 1381.7 & 8.9 \\
$\mathrm{Na}^{+}$ & IC & 445 & 198.7 & 4.8 \\
$\mathrm{NH}_{4}{ }^{+}$ & IC & 141 & 97.6 & 0.0 \\
$\mathrm{~K}^{+}$ & IC & 2705 & 1803.4 & 78.7 \\
$\mathrm{Ca}^{2+}$ & IC & 2409 & 959.2 & 2.3 \\
$\mathrm{Mg}^{2+}$ & IC & 223 & 125.8 & 0.0 \\
\hline
\end{tabular}

${ }^{\mathrm{a} X R F: ~ X-r a y ~ f l u o r e s c e n c e ; ~ I C: ~ I o n ~ c h r o m a t o g r a p h y . ~}$

TABLE 2: $\mathrm{PM}_{2.5}$ mass $\left(\mu \mathrm{g} / \mathrm{m}^{3}\right)$ and species concentrations $\left(\mathrm{ng} / \mathrm{m}^{3}\right)$.

\begin{tabular}{lcc}
\hline $\mathrm{PM}_{2.5}$ species & $\begin{array}{c}\text { December 31, } \\
\text { 2012-January 1,2013 }\end{array}$ & $\begin{array}{c}\text { January 2, } \\
\text { 2013-January 3, 2013 }\end{array}$ \\
\hline Mass & 104.9 & 103.7 \\
$\mathrm{Cl}^{-}$ & 1983.5 & 1160.5 \\
$\mathrm{NO}_{3}{ }^{-}$ & 2547.1 & 1502.4 \\
$\mathrm{SO}_{4}{ }^{2-}$ & 3542.0 & 1381.7 \\
$\mathrm{Na}^{+}$ & 445.4 & 198.7 \\
$\mathrm{NH}_{4}{ }^{+}$ & 141.3 & 97.6 \\
$\mathrm{~K}^{+}$ & 2705.4 & 1803.4 \\
$\mathrm{Ca}^{2+}$ & 2409.5 & 959.2 \\
$\mathrm{Mg}{ }^{2+}$ & 222.5 & 125.8 \\
$\mathrm{Al}$ & 5450.9 & 4097.6 \\
$\mathrm{Si}$ & 9756.6 & 6739.5 \\
$\mathrm{Ca}$ & 3356.8 & 1628.8 \\
$\mathrm{Ti}$ & 779.2 & 491.7 \\
$\mathrm{Fe}$ & 7616.0 & 5400.2 \\
$\mathrm{~V}$ & 10.3 & 7.9 \\
$\mathrm{Ni}$ & 3.2 & 11.1 \\
$\mathrm{~K}$ & 2969.2 & 1976.1 \\
$\mathrm{Se}$ & 0.0 & 0.7 \\
$\mathrm{Cl}$ & 1958.7 & 1047.5 \\
$\mathrm{Br}$ & 40.9 & 28.3 \\
$\mathrm{As}$ & 7.8 & 2.3 \\
$\mathrm{~Pb}$ & 22.9 & 632.7 \\
$\mathrm{Zn}$ & 90.0 & \\
$\mathrm{~S}$ & 1311.7 & \\
\hline
\end{tabular}

in Kampala are three and four times higher than the US 24hr $\mathrm{PM}_{2.5}$ National Ambient Air Quality Standards (NAAQS; $\left.35 \mu \mathrm{g} / \mathrm{m}^{3}\right)$ and the WHO air quality guidelines $\left(25 \mu \mathrm{g} / \mathrm{m}^{3}\right)$, respectively. This implies that air in Kampala could cause a suite of adverse health effects, especially in susceptible populations such as children and the elderly [3]. The observed $\mathrm{PM}_{2.5}$ levels in Kampala are comparable to the $\mathrm{PM}_{2.5}$ levels in other megacities in the developing world. For example,
TABLE 3: $\mathrm{PM}_{\text {coarse }}$ mass $\left(\mu \mathrm{g} / \mathrm{m}^{3}\right)$ and species concentrations $\left(\mathrm{ng} / \mathrm{m}^{3}\right)$.

\begin{tabular}{lcc}
\hline $\begin{array}{l}\text { Coarse PM } \\
\text { species }\end{array}$ & $\begin{array}{c}\text { December 31, } \\
\text { 2012-January 1, 2013 }\end{array}$ & $\begin{array}{c}\text { January 2, } \\
\text { 2013-January 3, 2013 }\end{array}$ \\
\hline Mass & 132.7 & 208.1 \\
$\mathrm{Mg}$ & 31.4 & 386.5 \\
$\mathrm{Al}$ & 694.8 & 6639.4 \\
$\mathrm{Ca}$ & 248.8 & 2324.4 \\
$\mathrm{~V}$ & 1.2 & 12.6 \\
$\mathrm{Cr}$ & 5.1 & 12.1 \\
$\mathrm{Mn}$ & 9.6 & 95.1 \\
$\mathrm{Fe}$ & 570.3 & 5163.0 \\
$\mathrm{Ni}$ & 0.6 & 4.0 \\
$\mathrm{Cu}$ & 2.2 & 7.4 \\
$\mathrm{Zn}$ & 5.9 & 35.8 \\
$\mathrm{Mo}$ & 0.1 & 0.7 \\
$\mathrm{Ag}$ & 0.0 & 0.1 \\
$\mathrm{Cd}$ & 0.0 & 0.0 \\
$\mathrm{Sn}$ & 0.0 & 0.6 \\
$\mathrm{Ba}$ & 3.3 & 28.9 \\
$\mathrm{Ce}$ & 1.6 & 15.0 \\
$\mathrm{Hg}$ & 0.6 & 3.6 \\
$\mathrm{~Pb}$ & 0.8 & 7.3 \\
\hline
\end{tabular}

the mean $\mathrm{PM}_{2.5}$ concentration in Beijing one month before the Olympic Games was $98.9 \pm 14.7 \mu \mathrm{g} / \mathrm{m}^{3}$ [14]; Cao et al. (2013) reported $24 \mathrm{hr} \mathrm{PM}_{2.5}$ concentrations ranged from $74.2 \pm 27.2 \mu \mathrm{g} / \mathrm{m}^{3}$ to $356.3 \pm 118.4 \mu \mathrm{g} / \mathrm{m}^{3}$ across 14 Chinese cities in the winter of 2003 and ranged from $27.3 \pm 11.0 \mu \mathrm{g} / \mathrm{m}^{3}$ to $131.6 \pm 28.0 \mu \mathrm{g} / \mathrm{m}^{3}$ in the summer of 2003 [15]. Kulshrestha et al. (2009) reported that the concentration of $\mathrm{PM}_{2.5}$ in Agra, India ranged from $22.8 \mu \mathrm{g} / \mathrm{m}^{3}$ to $215.1 \mu \mathrm{g} / \mathrm{m}^{3}$ with a mean of $104.9 \pm 47.1 \mu \mathrm{g} / \mathrm{m}^{3}$ and a standard deviation of $47.1 \mu \mathrm{g} / \mathrm{m}^{3}$ [16]. In a measurement campaign, Chow et al. (2002) reported that the mean and the maximum $\mathrm{PM}_{2.5}$ mass concentrations in Mexico City were 35.2 and $183.7 \mu \mathrm{g} / \mathrm{m}^{3}$, respectively [17]. It should be pointed out that the average concentrations from world cities mentioned above and in 
TABLE 4: Meteorological conditions during sampling.

\begin{tabular}{lcccc}
\hline Meteorological parameters & December 31, 2012 & January 1, 2013 & January 2, 2013 & January 3, 2013 \\
\hline Mean temperature, ${ }^{\circ} \mathrm{C}$ & 22.2 & 21.7 & 24.4 & 27.8 \\
Maximum temperature, ${ }^{\circ} \mathrm{C}$ & 25.0 & 26.1 & 20.6 & 26.7 \\
Minimum temperature, ${ }^{\circ} \mathrm{C}$ & 18.9 & 17.2 & 20.0 & 20.6 \\
Dew point temperature, ${ }^{\circ} \mathrm{C}$ & 18.9 & 19.4 & 8.1 & 20.0 \\
Mean wind speed, $\mathrm{Km} / \mathrm{hr}$ & 8.1 & 6.4 & 19.3 & 8.1 \\
Maximum wind speed, $\mathrm{Km} / \mathrm{hr}$ & 16.1 & 16.1 & 19.3 \\
\hline
\end{tabular}

December 31, 2012-January 1, 2013

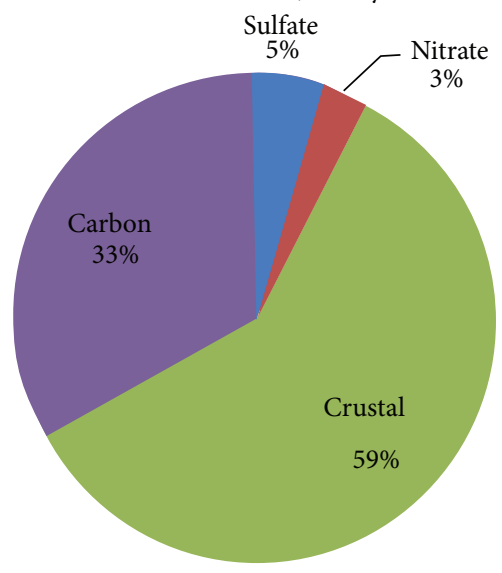

January 2, 2013-January 3, 2013

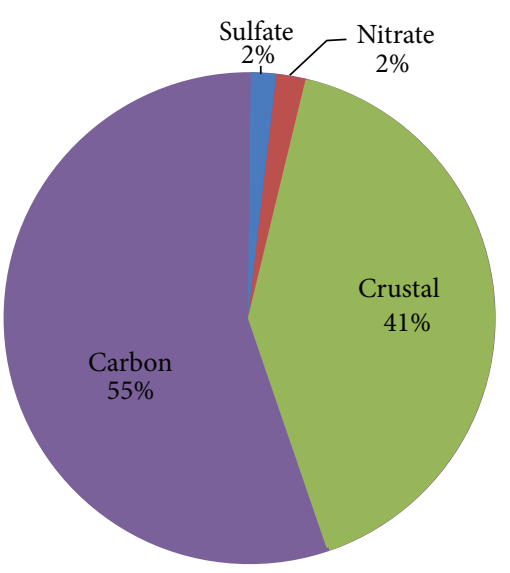

FIgURE 2: Twenty-four-hour average $\mathrm{PM}_{2.5}$ compositions of major components based on mass reconstruction, where fine soil $=2.2 \mathrm{Al}$ $+2.49 \mathrm{Si}+1.63 \mathrm{Ca}+2.42 \mathrm{Fe}+1.94 \mathrm{Ti}$ [9]. Ammonium $\left(\mathrm{NH}_{4}{ }^{+}\right)$ concentrations are low, so only sulfate and nitrate are included. The remaining $\mathrm{PM}_{2.5}$ mass is assumed to be carbon.

the literature were the monthly, seasonal, or annual average of measured daily $\mathrm{PM}_{2.5}$ concentrations. Therefore, caution needs to be exercised when comparing our results and the data presented in the literature.

Coarse particles collected in Kampala were primarily composed of crustal elements (i.e., $\mathrm{Al}, \mathrm{Ca}$, and $\mathrm{Fe}$ ), indicating soil dust as the major source. Unlike $\mathrm{PM}_{2.5}$, coarse particles are formed in the atmosphere through mechanical
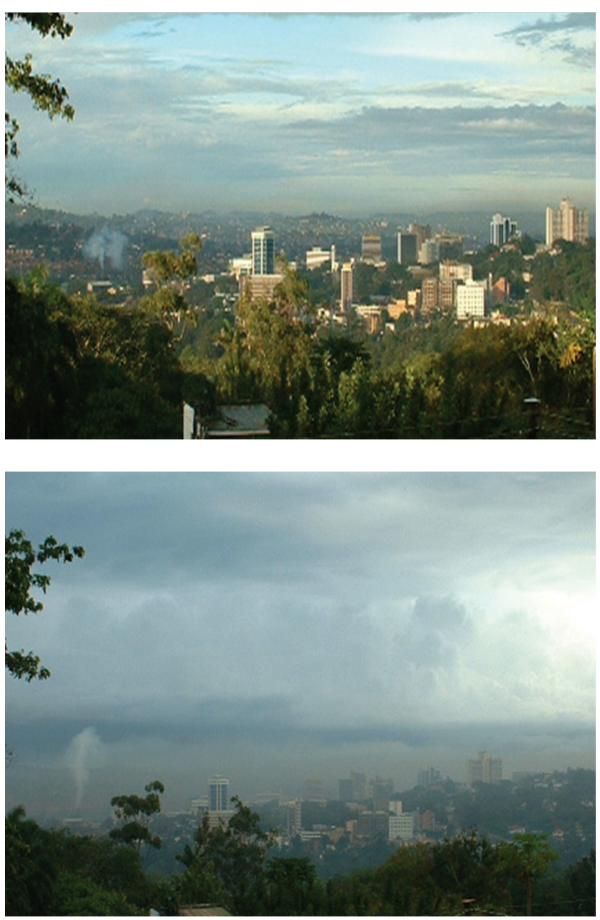

Figure 3: Views of the center of Kampala on a clear day (top) and a day with extensive air pollution (bottom).

forces, for example, the resuspension of road dust. Indeed, many unpaved road sections around the sampling area were observed by the authors. Other activities, such as agriculture, can also contribute to airborne coarse particles. These findings warrant further studies to examine the air pollutant source contributions.

Various anthropogenic sources appear to contribute to the elevated $\mathrm{PM}_{2.5}$ levels in Kampala. In 2011, the Uganda Revenue Authority (URA) estimated there were 635,656 vehicles in Uganda and about $50 \%$ of those were operating in greater Kampala [18]. Between 4,000 and 5,000 vehicles enter the country monthly from various countries $[8,19]$. These vehicles are mostly second-hand and purchased reconditioned from Japan. To date, there are no age restrictions and requirements for emission restrictions in place that exist in industrialized countries [20,21]. According to the Uganda National Environment Management Authority (NEMA), all the resulting daily traffic jams result not only in loss of valuable health and time but also lead to a loss of about 500 
million Uganda Shillings (about US \$200,000) in burnt fuel; that is, about 140,000 liters of fuel are burnt by idling cars every day [18].

Furthermore, the Bank of Uganda estimates that by 2003 there were 800,000 small scale enterprises in the entire country of Uganda, providing employment and income generation opportunities to low income sectors of the economy, but at the same time, potentially contributing to air pollution. In addition, there is no mandatory garbage collecting system in Kampala, Uganda. The majority of inhabitants has been and continues to simply burn their waste which includes a lot of plastics and results in toxic smoke.

The increased source emissions of $\mathrm{PM}_{2.5}$ may result from the rapid urbanization. The National Development Plan 2010-2015 estimates that Uganda's population could double to nearly 61 million in about 22 years [22]. The city has spread from the original 7 hills it sat on at independence in 1962, to approximately 50 now. City planners at the time planned urban infrastructure for approximately 500,000 residents. Today, Kampala has approximately 1,819,200 inhabitants (extrapolated from a population of 1,420,200 in 2008 and a population of 1,659,600 on June 16th 2011) and an additional estimated 2.5 million commuters from outside populating the roads of the city every day. Ever since independence no major infrastructural changes were initiated to accommodate this increase. The City's governing bodies are unable to cope with this massive population influx and the resulting consequences such as overcrowding, uncollected garbage, increased individual motor-vehicle traffic in absence of an organized public transport system, mostly on unpaved roads and uncontrolled informal markets, and small industries.

Given the evidence of abundant vehicle engine emissions and biomass burning in the PM samples from this study, future studies will have to include analysis of organic and elemental carbon as well as carbon speciation to further understand the source attribution and its potential health impacts. The current study is limited by a small sample size, limited PM speciation, assessment of PM at one location only, and by lack of seasonal assessments. The results of this pilot study are indicative of unhealthy air in Kampala and suggest that a large number of people may be threatened by cerebro- and cardiovascular as well as respiratory tract diseases and even diabetes mellitus resulting from air pollution exposure. Greater awareness and more extensive research on air pollution in Kampala are required to confirm our findings, to identify pollution sources that contribute to personal exposure, and to develop air quality management plans and policies to improve public health.

\section{Disclosure}

Melody Corry, who has M.S. and cand. Ph.D. degrees deceased five weeks before manuscript submission.

\section{Conflict of Interests}

The authors have no conflict of interests related to the conduct and reporting of this research.

\section{Acknowledgments}

The authors wish to acknowledge Mr. Peter Corry for his help providing location and assistance in setting up the sampler for particulate matter collection. This research was supported in part by NIEHS 5R01ES020382-02 (S. Schwander), the American Lung Association SB-230016-N (Q. Meng) and NIEHS P30ES005022. The content is solely the responsibility of the authors and does not necessarily represent the official views of the funding agencies partially supporting this work.

\section{References}

[1] WHO, "Global health risks. Mortality and burden of disease attributable to selected major risks," pp. 1-62, 2009.

[2] USEPA, "Integrated science assessment for oxides of Nitrogenhealth criteria," Tech. Rep., U. S. E. P. Agency, 2008.

[3] USEPA, "Integrated science assessment for particulate matter," Tech. Rep., U. S. E. P. Agency, 2009.

[4] B. R. Gurjar, T. M. Butler, M. G. Lawrence, and J. Lelieveld, "Evaluation of emissions and air quality in megacities," Atmospheric Environment, vol. 42, no. 7, pp. 1593-1606, 2008.

[5] J. Zhang, D. L. Mauzerall, T. Zhu, S. Liang, M. Ezzati, and J. V. Remais, "Environmental health in China: progress towards clean air and safe water," The Lancet, vol. 375, no. 9720, pp. 11101119, 2010.

[6] F. Lanyero, "Kampala chokes on pollution," in Daily Monitor (Uganda), 2011.

[7] N. Emmanuel, "Choking to death-air pollution in Kampala," in Kampala Dispatch, 2011.

[8] "Poisonous air engulfs Kampala," in New Vision (Uganda), 2011.

[9] W. C. Malm, K. A. Gebhart, J. Molenar, T. Cahill, R. Eldred, and D. Huffman, "Examining the relationship between atmospheric aerosols and light extinction at Mount Rainier and North Cascades National Parks," Atmospheric Environment, vol. 28, no. 2, pp. 347-360, 1994.

[10] J. G. Watson, J. C. Chow, and C. A. Frazier, "X-ray fluorescence analysis of ambient air samples," in Elemental Analysis of Airborne Particles, S. Landsberger and M. Creatchman, Eds., pp. 67-96, Gordon and Breach, 1999.

[11] J. C. Chow and J. G. Watson, "Ion chromatography in elemental analysis of airborne particles," in Elemental Analysis of Airborne Particles, S. Landsberger and M. Creatchman, Eds., pp. 97-137, Gordon and Breach, 1999.

[12] J. C. Chow, J. G. Watson, Z. Lu et al., "Descriptive analysis of PM2.5 and PM10 at regionally representative locations during SJVAQS/AUSPEX," Atmospheric Environment, vol. 30, no. 12, pp. 2079-2112, 1996.

[13] N. H. Frank, "Retained nitrate, hydrated sulfates, and carbonaceous mass in federal reference method fine particulate matter for six eastern U.S. cities," Journal of the Air and Waste Management Association, vol. 56, no. 4, pp. 500-511, 2006.

[14] J. F. Zhang, Cardiorespiratory Biomarker Responses in Healthy Young Adults to Drastic Air Quality Changes Surrounding the 2008 Beijing Olympics, Health Effects Institute, 2013.

[15] J.-J. Cao, Z.-X. Shen, J. C. Chow et al., "Winter and summer PM2. 5 chemical compositions in fourteen Chinese cities," Journal of the Air \& Waste Management Association, vol. 62, no. 10, pp. 1214-1226, 2012.

[16] A. Kulshrestha, P. G. Satsangi, J. Masih, and A. Taneja, "Metal concentration of PM2.5 and PM10 particles and seasonal 
variations in urban and rural environment of Agra, India," Science of the Total Environment, vol. 407, no. 24, pp. 6196-6204, 2009.

[17] J. C. Chow, J. G. Watson, S. A. Edgerton, and E. Vega, "Chemical composition of PM2.5 and PM10 in Mexico City during winter 1997," Science of the Total Environment, vol. 287, no. 3, pp. 177201, 2002.

[18] J. Ogwang, "500, 000 cars hit national roads in 20 years," in New Vision (Uganda), 2011.

[19] C. Obore, "Radioactive Japanese cars on the market," in Daily Monitor (Uganda).

[20] K. A. Tamale and S. Wamono, Transport and Environment Research Capacity and Needs in Uganda, Makerere University, 2010.

[21] P. Saundry, "Energy profile of Uganda," in The Encyclopedia of Earth, 2009.

[22] National Development Plan 2010/11-2014/15, 2010. 


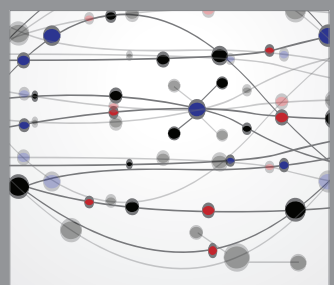

The Scientific World Journal
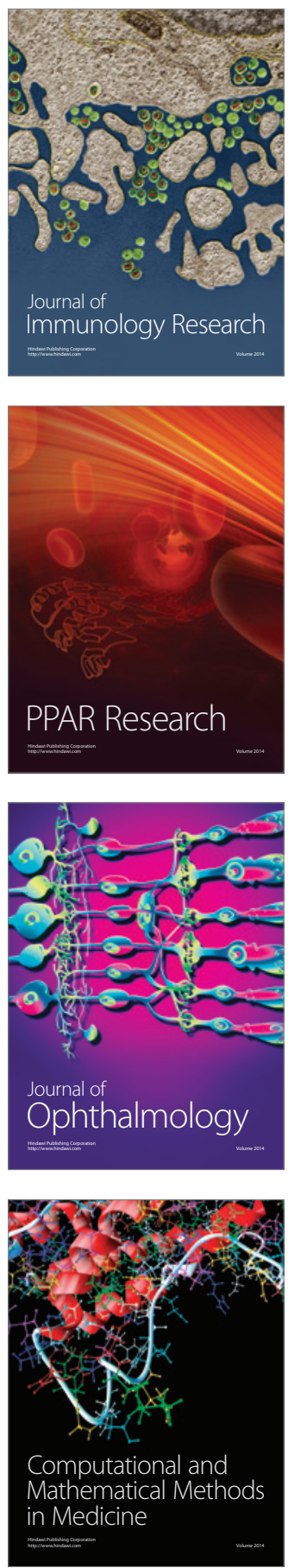

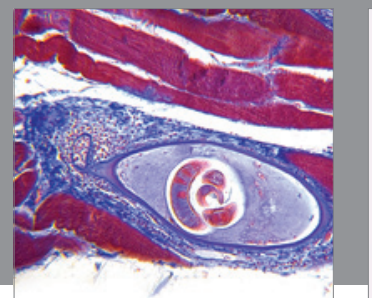

Gastroenterology

Research and Practice
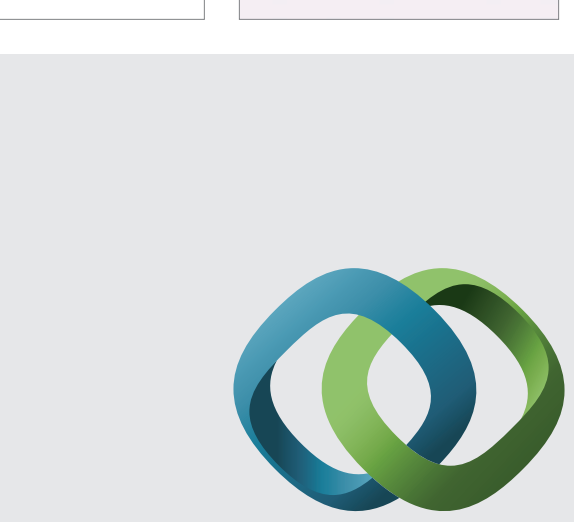

\section{Hindawi}

Submit your manuscripts at

http://www.hindawi.com
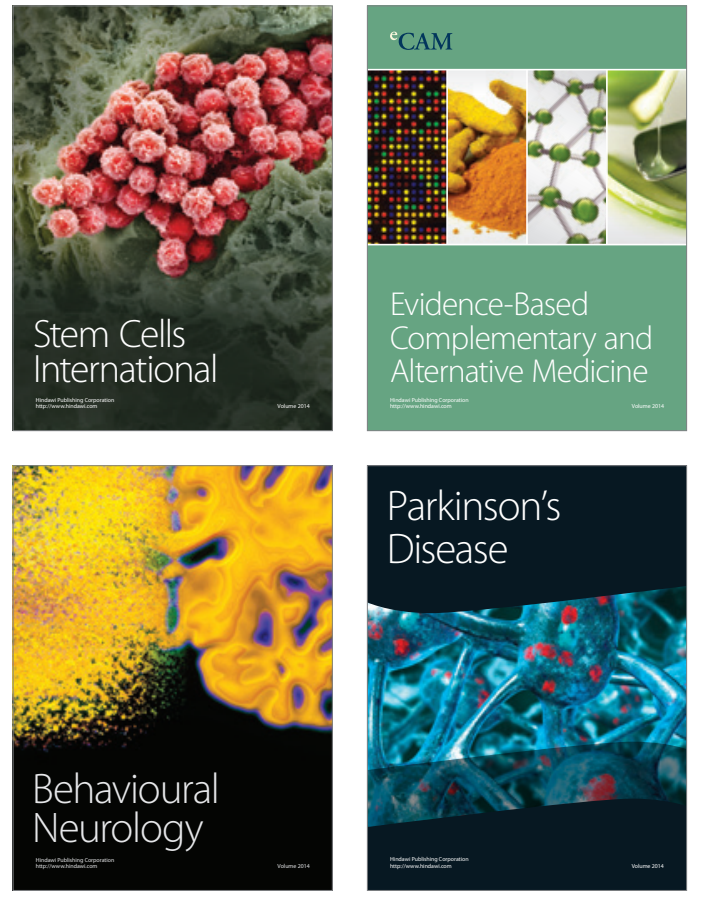
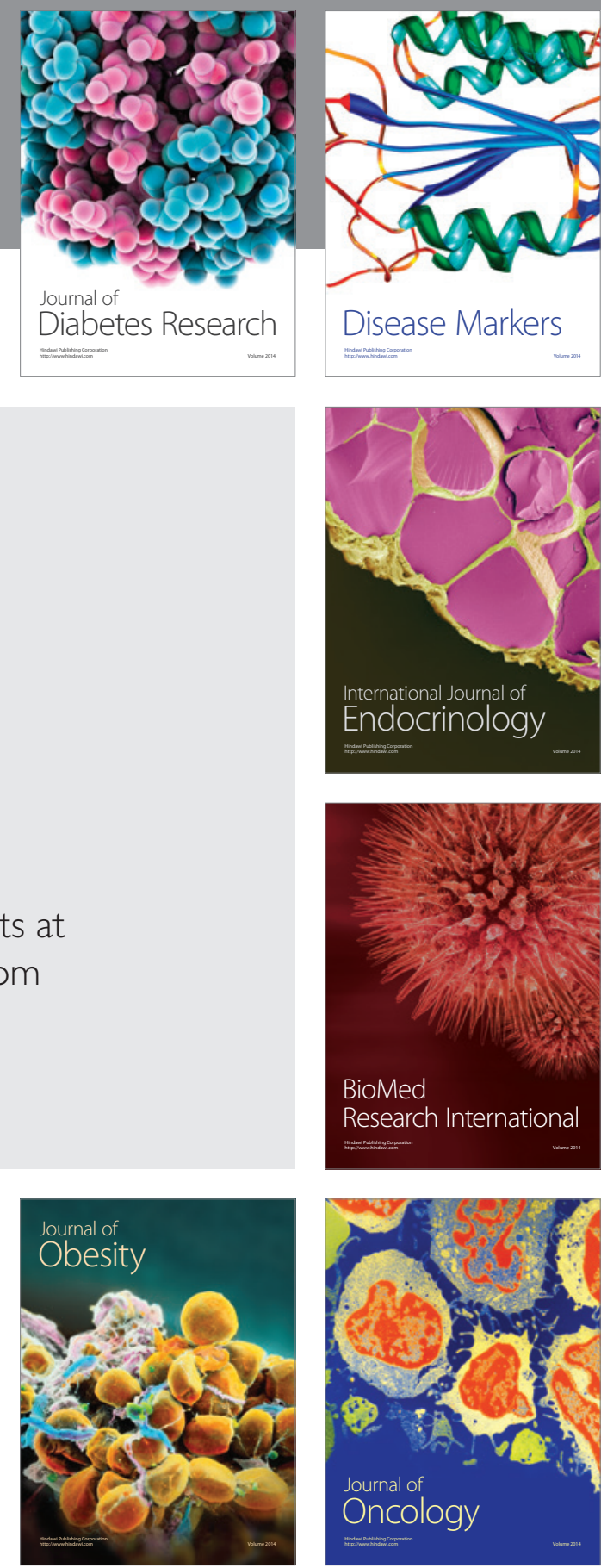

Disease Markers
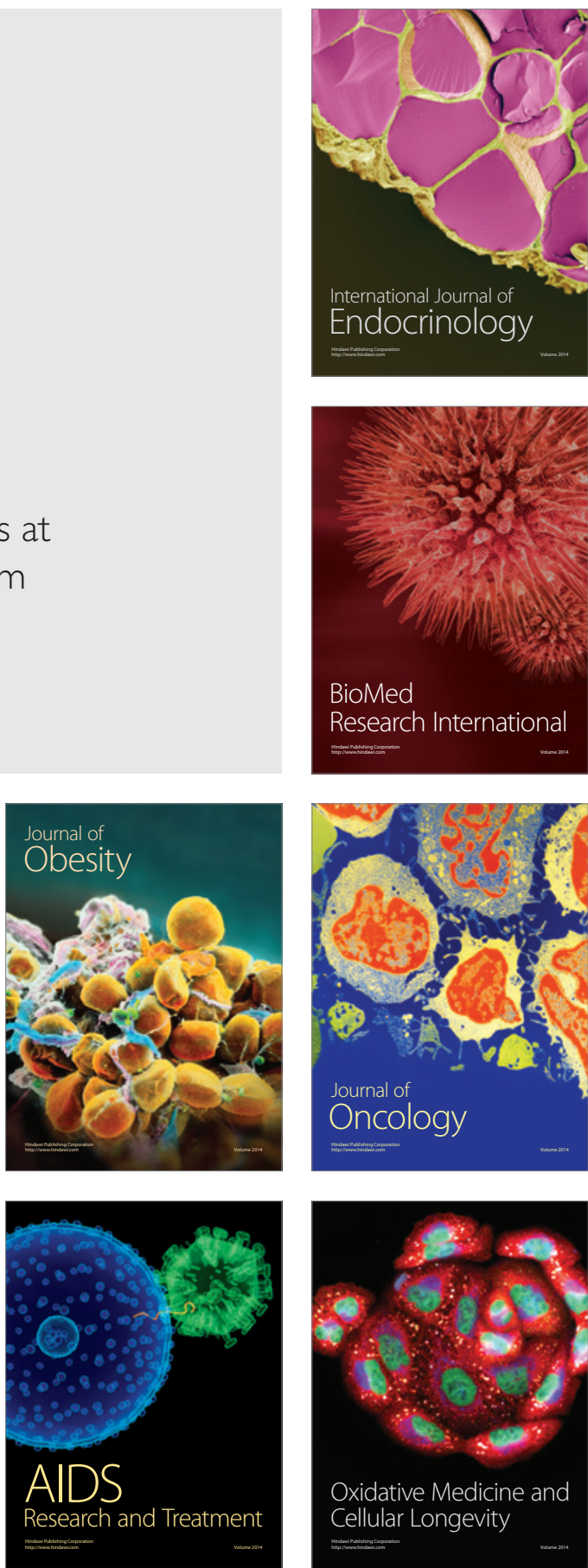